\title{
Interdisciplinary approach to flood risk and the Consequence of Flooding
}

\author{
Eva L. Suarez ${ }^{1, a}$ and Daniel E. Meeroff ${ }^{2}$ \\ ${ }^{1}$ Graduate Student, Department of Civil, Environmental and Geomatics Engineering, Florida Atlantic University, USA \\ ${ }^{2}$ Professor and Associate Chair, Civil, Environmental and Geomatics Engineering, Florida Atlantic University, USA
}

\begin{abstract}
This paper describes an alternate approach to prioritizing pluvial flood risk intervention strategies, and quantifying Consequence of Flooding (CoF) by applying the methodology of Failure Mode and Effect Analysis (FMEA). The intent is to develop an integrated, efficient, and quantitative $\mathrm{CoF}$ assessment approach to support pre-event efforts and post-event mitigation for flooding. The CoF assessment is based on three elements: (1) probability of flooding occurrence, (2) severity of the event, and (3) damage impact control. Two case studies are presented, one with an established Federal Emergency Management Agency (FEMA) zoning label, and the second for an unincorporated area in South Florida, USA. The results are compared with published values for flooding risk, and the outcome of the proposed method agrees with flood risk zoning label determined by FEMA. With the proposed alternate method, communities without FEMA classification due to lack of zoning map or data, could propose to FEMA potential flood insurance credit for premium reduction. This study also identified other elements to be included in future modelling efforts, such as elevation, to improve model development.
\end{abstract}

\section{Introduction}

The objective of this study is to develop a method for communities to achieve credit for developing a flood risk strategy where there is no data or mapping available. Currently, the Federal Emergency Management Agency (FEMA) methodology, provided by FEMA.gov website, consists of the following steps: (1) define the base topography, (2) evaluate the flood water level and storm surge, (3) define the cross-shore transects and primary frontal dune, (4) evaluate the storm-induced erosion and shore protection structures, (5) model the wave hazard, and (6) map the coastal flood hazard, to finally generate a Flood Insurance Rate Map (FIRM) of the flood zone.

Currently, flood risk is defined as the contribution from two components: the probability of the event and the consequence of adverse effects caused by the event (Teegavarapu, 2012, Zhou, et al., 2012; Purvis, et al., 2008). A straightforward approach to estimate the Consequence of Flooding $(\mathrm{CoF})$ is presented in this study for pluvial flooding in South Florida. It is based on the well-established Failure Mode and Effect Analysis method (FMEA) used extensively in the manufacturing and research industries to determine the risk of failure to products and industry processes, and even in the medical field (Cristaldi, et al., 2020; Gueorguiev, et al., 2020; Li, et al., 2020; Mascia, et al., 2020; Baynal, et al., 2018; Sellappan N. and K. Palanikumar, 2013; Rassiah, et al., 2020).

In this study the CoF contribution to flood risk, labelled as Risk Priority Number (RPN) in the FMEA method, is obtained by using the FMEA's outcome of three elements: (1) occurrence of flooding, (2) severity of the event, and (3) damage control. Similar to FMEA, the three elements are subdivided into ten sectors, as a function of the probability of the element's influence into $\mathrm{CoF}$. The sum of the outcome for the three element generates the CoF score, later to be used for flood intervention strategies.

The occurrence of flooding, or recurrence interval, is defined as the mean time between flooding from an ordinary 1-hour duration in 2-year recurrence interval to 3day duration in 100-year recurrence interval. The flooding occurrence scale follows the FMEA format, which ranges from one to ten, where almost persistent flooding is ten, with an occurrence exceedance probability of 0.5 , and extremely remote recurrence of flooding is one, with an occurrence exceedance probability of 0.01 , per the American Society for Quality.org site on 2020.

The severity of the flooding is measured by property damage based on the depth of inundation, and it follows the FEMA Multi-hazard loss estimation methodology (Hazus ${ }^{\circledR}$ ). The severity of flooding is evaluated on a scale from one to ten. One is assigned when there is no impact to the wellbeing of the community, and ten is assigned when the damage accumulated is detrimental to human life. The outcome of the assessment is used to calculate the CoF.

The third element, damage impact control, being damage reduction or damage avoidance, is estimated from temporal assessment of development pressures, such as, progressive population variation and decreased flood 
resilience due to impact area imperviousness. The damage scale also ranges from one to ten. One is assigned for an extremely low probability of flooding due to developmental pressures, and ten is assigned for a scenario that is almost certain to occur due to the anthropogenic effect by the community.

Lastly, the paper outlines a methodology to estimate the CoF from flooding events, and provides a prioritization risk-reduction strategy, targeting credit under the National Flood Insurance Program (NFIP) Community Rating System (CRS) classification process, which will eventually achieve flood insurance premium reduction. The method could be expanded to include the consequences of coastal surge generation and propagation, and fluvial flooding interaction with pluvial flooding, maximizing synergies for flood risk management (Tanaka, et al., 2020; Khanal, et al., 2019; Chen, et al., 2010).

\section{Background}

Climate change in the last 30 years has impacted the frequency of flooding events, and the mean time between flooding has become a dynamic variable for the risk of flooding analysis. Several studies have been conducted to prioritize and estimate the impact of a single flooding event for economics and health related issues (Bell, J., et al., 2017; Grames, et al., 2016; Jonkman, et. al., 2008; Vrouwenvelder, 2007; Asselman and Jonkman, 2003). However the combination and interaction of elements has only recently been investigated (Frame, et al. 2020). For example, the severity of persistence of flooding over a particular impervious area and the interaction with the impact of anthropogenic activity in a rapid developing sector, has not been incorporated into the flood risk model.

Previous modelling efforts used optimization of socioeconomic inputs and the uncertainty associated with the flood damage model to assess the CoF, and to mitigate a predicted failure into the flood risk analysis (Makwana and Thakkar, 2014; Bubeck et. al., 2011). This study presents an approach used in the manufacturing industry, analogous to the Six Sigma risk management approach. However, instead of using the standard Six Sigma for quality strategy, this study modified the concept of Consequence of Failure from the manufacturing industry into the Consequence of Flooding $(\mathrm{CoF})$. The forecasting model, based on probability theory, estimates the $\mathrm{CoF}$ into a given area as a function of probability of occurrence, the severity of the different scenarios, and the damage incurred by the flooding event.

The impact FEMA Community Rating System (CRS) have into public awareness and the insurance premiums is a function of flooding consequences. Previous studies to model public awareness of upcoming flooding was considered a crucial aspect in flood risk management (Kellens, et. al. 2011; Bubeck, et. al. 2016; Grahn 2017). Variables such as location, as well as personal and residential characteristics, were included in those models of perceived hazard from coastal flooding. This study includes a range of predictive variables that allows for objective prioritization of mitigation strategies.
A recently proposed flood risk calculation established the flood risk score as a function of the Likelihood of Failure (LoF) and Consequence of Failure (Scott and Smith, 2019; Alexander, et al., 2011). However, their risk score has subjective elements, based on the opinion of a committee of experts, following Delphi techniques, rather than a more objective probabilistic method as proposed in this study.

Other recent attempts to quantify flood risk to a range of socio-economic variables is in the development phase by the Southeastern University Research Association (Wright et al., 2020). They published a white paper recognizing how objective and quantifiable risk assessment is critical to prioritizing strategies and resource allocation in support of communities' resilience to climate hazards and storm impacts. In addition, a project at Florida Atlantic University (FAU), funded by the Florida Division of Emergency Management (FDEM), provides guidance to vulnerable regions on how best to concentrate resources for maximum mitigation benefit (Bloetscher et al., 2020; Meeroff and Bloetscher, 2020). The screening tool provides an initial risk assessment focused on the hydrologic response to a specified rainfall event given certain key features of the sub-watershed. This tool gives an overview of the driving factors and a pre-assessment where this study calculated CoF for flood risk assessment should converge. The modified FMEA, and calculated CoF provides a format to link projected challenges with the most cost-effective solutions, and deliver a strategy to prevent or mitigate flood risk.

Lastly, an attempt to re-label the occurrence of storm events has been proposed (Grisa, 2012) with lukewarm approval from the technical community. The logical approach was not tied to flooding, rather to rainfall event intensity, frequency and duration. The authors of this paper incorporated and expanded the methodology from Grisa (2012), and applied it to the National Oceanographic and Atmospheric Agency (NOAA) site number 08-0845 at Boca Raton, Florida, for reference. The calculated flood occurrence values used the 3-day, 100-year storm event as the base in this study.

The use of FMEA to assess potential problems and mitigation solutions is well known in the industry, however its application to calculate flooding consequences is a new application of this manufacturing methodology.

\section{Discussion}

In this research the authors used a modified FMEA method to calculate the CoF. This alternate $\mathrm{CoF}$ calculation was used in two case studies in Florida, to demonstrate the applicability of the proposed method.

\subsection{Flooding occurrence}

Flooding occurrence is defined as the mean time between flooding events, or recurrence, and is a function of storm event impact, soil saturation capacity, tide cycle, wave heights, storm angle, barometric pressure, bathymetry measurements, and storm surge reach. From those mentioned, the two factors used on this study to determine 
the flood occurrence were the storm event impact, based on the intensity, duration, and frequency; and the soil capacity to absorb the water.

Maximum annual values from NOAA Atlas 14 Volume 9 Version 2.0 Precipitation Frequency Data Server at Site ID: 08-0845, latitude $26.3675^{\circ}$ longitude $80.1108^{\circ}$ Boca Raton, Florida, period of record 01/1942 to $12 / 2010$, were used to generate the Occurrence Exceedance Probability (OEP) chart in Table 1 (Perica et al., 2013). NOAA's procedure for developing an Annual Maximum Series (AMS) included extracting only reasonable maxima, if a year was incomplete. Missing data occurred in some South Florida records where observations were not taken regularly. All annual maxima that resulted from missing data were highlighted and screened to ensure incomplete data did not biased the results.

The OEP value was obtained from the mean time between flooding (1/years), also called recurrence. For example, a frequency of 2-year recurrence equals $1 / 2$ probability of occurrence exceedance. The format for Table 1 was previously derived by Grisa (2010) and modified to the FMEA format, where storm duration was considered from 1-hour to 3-days, and the recurrence intervals were defined from 2-years to the 100 -year storm, which translate into an OEP from 50 percent to 1 percent.

\begin{tabular}{|l|l|l|l|l|l|}
\hline \multirow{2}{*}{$\begin{array}{l}\text { Storm } \\
\text { duration }\end{array}$} & \multicolumn{5}{|c|}{ Maximum Storm Intensity (inches) } \\
\cline { 2 - 6 } & $\begin{array}{l}\text { OEP } \\
50 \%\end{array}$ & $\begin{array}{l}\text { OEP } \\
10 \%\end{array}$ & $\begin{array}{l}\text { OEP } \\
4 \%\end{array}$ & $\begin{array}{l}\text { OEP } \\
2 \%\end{array}$ & $\begin{array}{l}\text { OEP } \\
1 \%\end{array}$ \\
\hline 1-hr & 2.35 & 3.56 & 4.26 & 4.81 & 5.37 \\
\hline 2-hr & 2.99 & 4.54 & 5.46 & 6.18 & 6.91 \\
\hline 3-hr & 3.36 & 5.16 & 6.26 & 7.13 & 8.04 \\
\hline 6-hr & 3.96 & 6.32 & 7.84 & 9.09 & 10.4 \\
\hline 12-hr & 4.52 & 7.61 & 9.7 & 11.5 & 13.3 \\
\hline 24-hr & 5.14 & 8.89 & 11.5 & 13.7 & 16.1 \\
\hline 3-days & 6.59 & 10.6 & 13.5 & 15.9 & 18.6 \\
\hline
\end{tabular}

Table 1. Storm intensity, duration and frequency per OEP

The depth of the flooded area is directly correlated with the soil capacity to absorb the storm. This analysis involves the dominating soil type. Other variables, such as topography and slope have less impact in the South Florida flooding occurrence scheme. The Hydrologic Soil Groups (HSG) classification from the Natural Resource Conservation Services (NRCS) was used to determine the soil capacity ranking in South Florida. The standard classification was: HSG group A for soils with high infiltration rates, even when thoroughly wetted, low runoff potential, and a final infiltration rate of 0.30 to 0.50 inches/hour. HSG group B was given to soils with moderate infiltration rates when thoroughly wetted, slight runoff potential, and a final infiltration rate of 0.15 to 0.30 inches/hour. HSG group C was given to soils with slow infiltration rates when thoroughly wetted, moderate runoff potential, and final infiltration rate of 0.05 to 0.15 inches/hour. Lastly HSG group D was given to soils with very slow infiltration rates when thoroughly wetted, high runoff potential, and final infiltration rate of less than 0.05 inches/hour. The HSG factor was incorporated with the seven different soil orders in Florida, and a rating for flood occurrence was determined for the state (Table 2).

Approximately 45 percent of the soils in Florida are classified as HSG groups A and B, with 28 percent as HSG group $\mathrm{C}$ and 27 percent as HSG group D. The United States Department of Agriculture (USDA) soil texture classification for the first case study, where FAU is located, is mostly HSG group A: sandy soils, muck, or fine sandy-loams (Mylavarapu, R., et al., 2016; McCollum et al. 1974). Approximately 2 percent of the soils at Palm Beach County (PBC) are sandy clay loam, with a higher water retention capacity and lower infiltration rate when compared to the soils in the rest of Florida, however this type of soil is not at the current site location used for this study.

The soil texture at the locations investigated for this study were classified as mostly sandy and some sandyloams, where permeability is rapid in the surface and subsurface layers, and moderate in the subsoil (McCollum et al. 1974). For this study an average percolation rate of 0.5 inch per hour and a maximum soil water content capacity of 15 percent were considered (O'Geen 2013). These values were used to calculate the flooding occurrence rating based on the infiltration rate for the maximum storm intensities in Table 1. Flooding occurrence rating for the PBC location falls between 1 and 3 , when the rate of rainfall is greater than 1.0 inch per hour. The flooding occurrence rating will be used to determine the CoF later in the analysis.

\begin{tabular}{|c|l|}
\hline $\begin{array}{c}\text { Flooding } \\
\text { Occurrence } \\
\text { Rating }\end{array}$ & $\begin{array}{c}\text { Infiltration Rate } \\
\text { (inches per hour) }\end{array}$ \\
\hline 1 & $>0.50$ \\
\hline 2 & $0.40-0.50$ \\
\hline 3 & $0.30-0.40$ \\
\hline 4 & $0.25-0.30$ \\
\hline 5 & $0.20-0.25$ \\
\hline 6 & $0.15-0.20$ \\
\hline 7 & $0.10-0.15$ \\
\hline 8 & $0.05-0.10$ \\
\hline 9 & $0.01-0.05$ \\
\hline 10 & $<0.01$ \\
\hline
\end{tabular}

Table 2. Flooding occurrence allocations per soil capacity and infiltration rate

\subsection{Severity of the event}

FMEA severity is defined as the effect of the failure impact to residents. To quantify severity of flooding, the depth of inundation was used. Severity was defined as percent loss from inundation level. Each structure or building has its own inundation damage function per FEMA Multi-hazard Loss Estimation Methodology Flood 
Model $\left(\right.$ Hazus $^{\circledR}$ ) developed by the Department of Homeland Security. The Hazus ${ }^{\circledR}$ model is used by FEMA to estimate property losses, from one-story residences to multi-level buildings. For example, a single-story residence without basement, typical in the area covered by this study, would follow an inundation depth-damage function as depicted in Figure 1, where the most likely damage would be close to 18 percent the value of the residence for a 1-foot inundation, and for 5 feet of inundation, up to 40 percent the value of the property. However, it may withstand as high as 30 percent maximum damage for the same one foot of flooding water. A scale from one to ten assigns values based on the criteria defined above. Table 3 was specifically established for the case study considered later in this project. Similar approach could be used for other buildings and flooding scenarios. This ranking was used as a variable in the calculation of the $\mathrm{CoF}$.

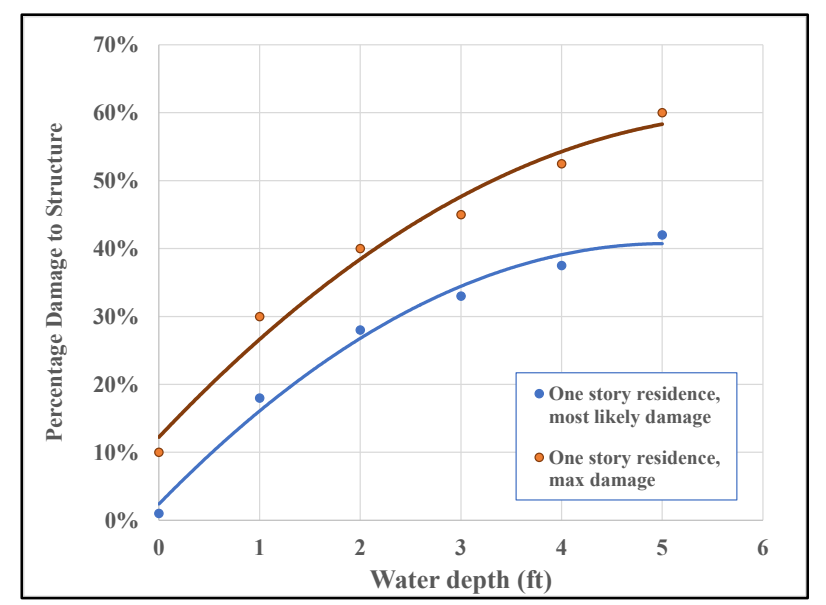

Figure 1. Example of FEMA Depth Damage Functions

\begin{tabular}{|c|c|}
\hline Rating & Severity description \\
\hline 1 & $\begin{array}{l}\text { No property impact from flooding, nor to the } \\
\text { well-being of the community }\end{array}$ \\
\hline 2 & Temporary relocation, no damage to property \\
\hline 3 & Relocate, property damage less than $1 \%$ \\
\hline 4 & $\begin{array}{l}\text { Minor effect, less than } 5 \% \text { property replace } \\
\text { value }\end{array}$ \\
\hline 5 & $\begin{array}{l}\text { Moderate effect, less than } 18 \% \text { property replace } \\
\text { value }\end{array}$ \\
\hline 6 & Significant effect, $28 \%$ property replace value \\
\hline 7 & $\begin{array}{l}\text { Major effect, inundation that exceeds } 40 \% \\
\text { property replace value }\end{array}$ \\
\hline 8 & $\begin{array}{l}\text { Extreme effect, inundation that exceeds } 50 \% \\
\text { property replace value }\end{array}$ \\
\hline 9 & $\begin{array}{l}\text { Serious effect, total building replace value, and } \\
\text { economic activity and community, parcel, or } \\
\text { watershed disfunction }\end{array}$ \\
\hline 10 & Hazardous effect, detrimental to human life \\
\hline
\end{tabular}

Table 3. Severity allocations per incurred property loss

\subsection{Damage impact control}

Flood damage impact control is the combination of damage reduction and damage avoidance. Damage reduction is based on resolution after flooding, while damage avoidance is preventive measure prior to a flooding event. Damage reduction, by resolution, are quality control challenges, such as, environmental and political water resources management, reservoir releases, spills, and equipment damages.

Conversely, damage avoidance is achieved by mitigating and implementing preventive measures. Damage avoidance uses projected anthropogenic impacts due to development pressures: land use, urbanization and population change, and planned percent impervious surface for development areas (new roads, parking lots, buildings, and other structures). The focus of this alternate method is to establish a model to prevent flooding, rather than resolution after flooding.

The Environmental Protection Agency, Report on the Environment (EPA-ROE, 2020) defined two indicators for impact to area utilization changes, and consequently, increased propensity to flooding: land use and urbanization and population change. The term land use describes the economic and population cultural activities at a location. Urbanization and population changes are related to the U.S. Census Bureau, annual population estimates, and data collected by the USDA Natural Resources Conservation Service's National Resources Inventory (NRI) to track developed land. The intent is to capture trends in overall population growth for both rural and urban populations, the amount of developed land relative to the amount of population change, and overall population density. Table 4 depicts the development growth in South Florida, using data from Pompano Beach, FL.

The last factor considered is the amount of impervious area defined for a parcel of land. The U.S. Department of the Interior and U.S Geological Survey established six classes of impervious cover, in order of impact to natural water flow: buildings, roads, parking lots, driveways, sidewalks, and other minor obstacles, such as pavers, large stones, and gravel. They used a digitized spatial resolution aerial imagery to quantify imperviousness (Tilley and Slonecker 2007). Their assessment was modified for this study, where the authors used the percent of impervious areas as it applied to South Florida (Table 5).

\begin{tabular}{|c|c|c|}
\hline $\begin{array}{c}\text { Census } \\
\text { year }\end{array}$ & $\begin{array}{c}\text { Population } \\
\text { density } \\
\text { (per square } \\
\text { mile) }\end{array}$ & $\begin{array}{c}\text { Imperviousness } \\
(\%)\end{array}$ \\
\hline 2010 & 4159.8 & 70 \\
\hline 2000 & 3257.9 & 50 \\
\hline 1980 & 2442.4 & 30 \\
\hline
\end{tabular}

Table 4. South Florida land population density impact (Pompano Beach, FL) 


\begin{tabular}{|c|c|l|}
\hline $\begin{array}{c}\text { Imperviousness } \\
(\%)\end{array}$ & Categorized & \multicolumn{1}{|c|}{ Description } \\
\hline$>40$ & Severe & $\begin{array}{l}\text { Area covered with } \\
\text { asphalt, self- } \\
\text { standing dwelling } \\
\text { and structures }\end{array}$ \\
\hline $25-40$ & $\begin{array}{l}\text { Degraded/Non } \\
\text {-supportive }\end{array}$ & $\begin{array}{l}\text { High frequency of } \\
\text { flooding }\end{array}$ \\
\hline $11-25$ & Impacted & $\begin{array}{l}\text { Moderate } \\
\text { frequency of } \\
\text { flooding }\end{array}$ \\
\hline $2-10$ & $\begin{array}{l}\text { Stressed/ } \\
\text { Sensitive }\end{array}$ & $\begin{array}{l}\text { No frequency } \\
\text { flooding }\end{array}$ \\
\hline$<2$ & Undisturbed & Natural landscape \\
\hline
\end{tabular}

Table 5. South Florida soil imperviousness impact distribution

The relationship between the percent imperviousness and the population density, Figure 2, was used to develop the criteria to assess the probability of damage avoidance, that is probability of success, as shown in Table 6. Figure 2 shows a scale for population density up to 5000 people per square mile. With the exception of Miami, the rest of South Florida falls below the 5000 people per square mile limit. A scale from one to ten is used as a factor of preemptive damage control, per FMEA method. For example, an area with less than 10 percent imperviousness, and population density below 2500 people per square mile, is 98 to 100 percent prepared to mitigate the 100 -year storm.

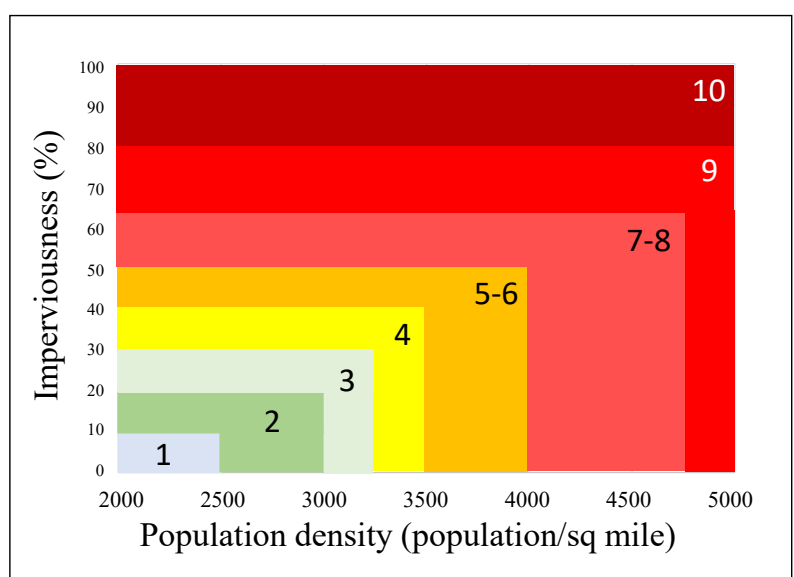

Figure 2. South Florida land development growth relation to area imperviousness

\begin{tabular}{|c|c|}
\hline Rating & Flood damage control assessment \\
\hline 1 & $>97 \%$ probability of successfully avoid damage \\
\hline 2 & $93 \%$ probability of minimum flooding damage \\
\hline 3 & $88 \%$ probability of avoiding flooding damage \\
\hline 4 & $\begin{array}{l}80 \% \text { moderate probability of avoiding flooding } \\
\text { damage }\end{array}$ \\
\hline $5-6$ & $\begin{array}{l}67 \% \text { low probability of avoiding flooding } \\
\text { damage }\end{array}$ \\
\hline $7-8$ & $\begin{array}{l}40 \% \text { probability, slight possibility of avoiding } \\
\text { damage }\end{array}$ \\
\hline 9 & $\begin{array}{l}20 \% \text { probability, remote possibility of avoiding } \\
\text { damage }\end{array}$ \\
\hline 10 & $\begin{array}{l}<1 \% \text { probability, no control, damage } \\
\text { unavoidable }\end{array}$ \\
\hline
\end{tabular}

Table 6. Damage allocations per flooding events

\subsection{Consequence of Flooding}

The Community Rating System (CRS) specifies in Section 410 Flood Hazard Mapping, the process of accurately mapping the flood-prone communities based on accumulated flood hazard data. An abridged list of FEMA Special Flood Hazard Areas (SFHA) and zones outside of the SFHA, with a brief description, is provided in Table 7. Flood zones identified by the letters A or V represent highrisk areas, and zones identified with the letter $\mathrm{X}$ represent areas with moderate or minimal flood hazard.

\begin{tabular}{|c|l|}
\hline $\begin{array}{c}\text { FEMA } \\
\text { Zone }\end{array}$ & \multicolumn{1}{c|}{ Description } \\
\hline A & $\begin{array}{l}\text { SFHA where no base flood } \\
\text { elevation is provided }\end{array}$ \\
\hline AR & $\begin{array}{l}\text { Temporary designation, base } \\
\text { flood to be improved, part of } \\
\text { SFHA }\end{array}$ \\
\hline AE & $\begin{array}{l}\text { SFHA where base flood } \\
\text { elevations ae provided. }\end{array}$ \\
\hline AH & $\begin{array}{l}\text { Shallow flooding SFHA. Base } \\
\text { flood elevations related to } \\
\text { national datum are provided. }\end{array}$ \\
\hline D & $\begin{array}{l}\text { Undetermined area, but possible } \\
\text { flood hazard }\end{array}$ \\
\hline V & $\begin{array}{l}\text { SFHA subject to coastal high } \\
\text { hazard flooding }\end{array}$ \\
\hline $\mathrm{X}$ & $\begin{array}{l}\text { Moderate or minimal flood } \\
\text { hazard, less than one foot. }\end{array}$ \\
\hline
\end{tabular}

Table 7. FEMA flooding zone ranking

The calculated CoF range aligns with the FEMA zone ranking, providing a link to flood risk mitigation plans, and in some cases, providing a strategy to identify potential flooding challenges. The CoF is calculated by Equation (1).

$$
\text { CoF }=(\text { Occurrence })+(\text { Severity })+(\text { Impact })
$$

The maximum possible value for $\mathrm{CoF}$ is 30 , and the minimum is three. When the calculated $\mathrm{CoF}$ is below or equal to 6 , no actions are required and the classification should be Zone $\mathrm{X}$. When the CoF value is greater than or equal to 27 , if the area is unincorporated or labelled Zone $\mathrm{D}$, the recommendation is to change to Zone $\mathrm{V}$ and apply the mitigation measure against flooding. $\mathrm{CoF}$ values between 6 and 26 should be labelled Zone AR if mitigation is planned for the near future, and Zone $\mathrm{A}$ if there is no plan to mitigate within the next three years.

\subsection{Case studies}

The CRS indicates how FEMA will provide credit for developing flood risk management strategies when there is no data to support the Flood Insurance Rate Map (FIRM) activity. This is an opportunity to evaluate an alternate method to fill the flooding maps for insurance purposes. The objective of this study is to develop a method for communities to achieve this credit, particularly when there is no data or map from FEMA. To validate the alternate 
method, two areas were selected. One case was conducted to demonstrate similar results to the official FEMA method, and a second case was conducted to predict the FEMA zone when none is provided.

The area selected for the first case study is a parcel at Florida Atlantic University (FAU), near the Boca Raton Water and Wastewater Treatment Facility (Figure 3). The area is located at latitude $\mathrm{N} 26.3684^{\circ}$ and longitude W80.1088 . Figure 4 depicts the Zone assignment per current FIRM.

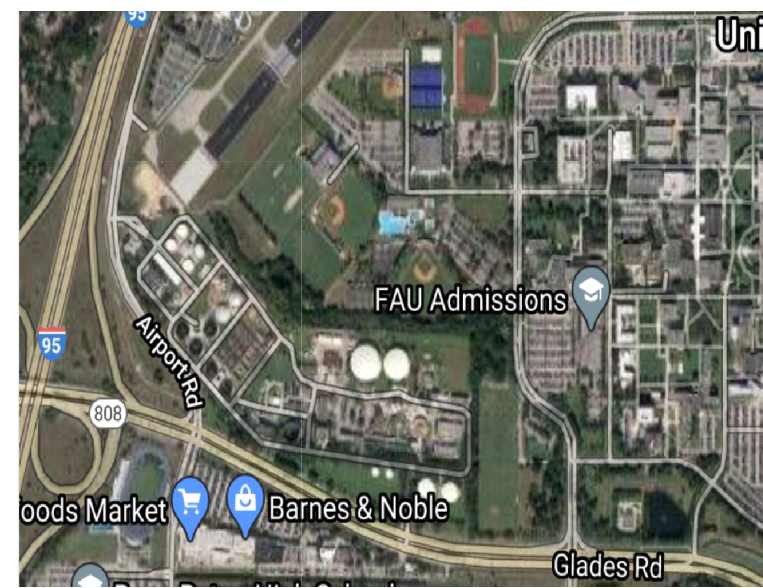

Figure 3. Case 1 illustration of study area

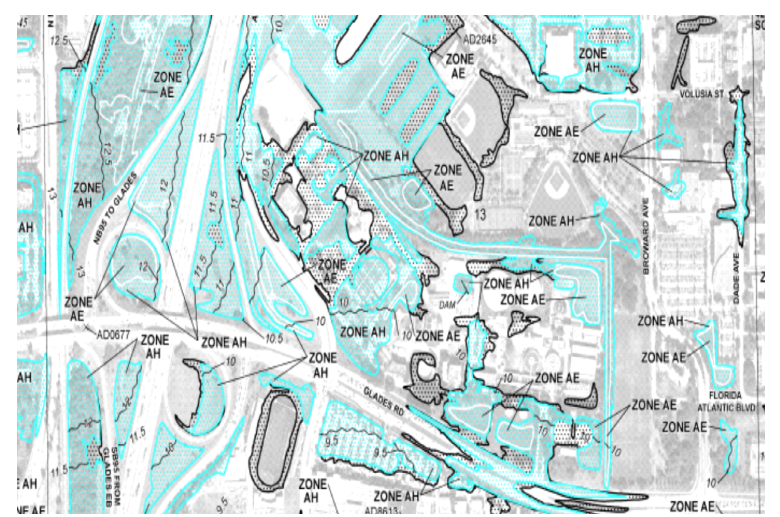

Figure 4. FIRM depiction for case 1 area

Results for case study one, using the alternate flood risk assessment, are given in Table 8. The area is classified by FEMA CRS as AH, that is, shallow flooding SFHA with base flood elevations in relation to a national datum. The occurrence exceedance probability of six was assigned given the propensity of occasional flooding in the area, due to a mean elevation of 16 feet (Kanelidis 2020). Severity of event and damage control were assigned a value of two since the occasional flooding does not cause damage to the property, it is mostly an open area used for outside sport activities. A CoF of ten will identify this area for further investigation, and assign a temporary zone value of AR. The zone classification of AR precedes the $\mathrm{AH}$ assignment when the base flood elevations are included in the map.

\begin{tabular}{|c|c|l|}
\hline $\begin{array}{l}\text { Risk } \\
\text { elements }\end{array}$ & Allocation & Explanation \\
\hline OEP & 6 & $\begin{array}{l}\text { Medium flooding frequency, } \\
\text { elevation below 16 feet. }\end{array}$ \\
\hline Severity & 2 & $\begin{array}{l}\text { Minor severity, no damage } \\
\text { cost due to open area usage }\end{array}$ \\
\hline Damage & 2 & $\begin{array}{l}\text { Preventive measures in place, } \\
\text { drainage installed to prevent } \\
\text { flooding }\end{array}$ \\
\hline CoF & $\mathbf{1 0}$ & $\begin{array}{l}\text { Zone AR. Assess for AE, if } \\
\text { base flood elevations are } \\
\text { available, or AH if shallow } \\
\text { flooding and SFHA. }\end{array}$ \\
\hline
\end{tabular}

Table 8. Case 1 alternate method ranking results

The second test case was conducted in an unincorporated area in South Florida. FEMA uses Zone D for areas where there are undetermined flood hazards and risk of flooding, however no analysis of flood hazards has been conducted; or when a community incorporates portions of another community's area where no map has been prepared. Mandatory flood insurance does not apply, it is left to public awareness and property owner pro-action to buy coverage, which exposes the property owner to potential economic losses, especially while in the process of mapping the area.

Case two is an example of an unincorporated area in Palm Beach Gardens, FL surrounded by an area with detailed FIRM mapping and Zone AE (Figure 5). The data for this area was obtained from the Palm Beach Gardens Document Center depository. PBG population density is 986 people per square mile. The results for case two are summarized in Table 9. The $\mathrm{CoF}$ for the area aligns with the expected value, based on the surrounding FEMA FIRM allocations.

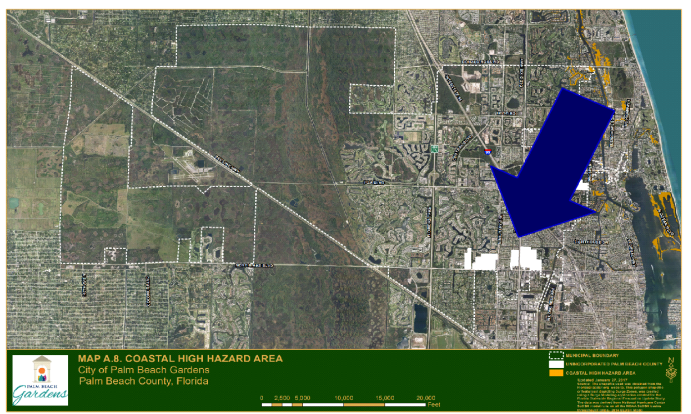

Figure 5. Illustration of unincorporated area of case 2

\begin{tabular}{|c|c|l|}
\hline $\begin{array}{l}\text { Risk } \\
\text { elements }\end{array}$ & Allocation & Explanation \\
\hline OEP & 2 & $\begin{array}{l}\text { Remote, unlikely, with } \\
\text { elevation above 16 feet. }\end{array}$ \\
\hline Severity & 3 & $\begin{array}{l}\text { No property damage, or } \\
<\$ 1000\end{array}$ \\
\hline Damage & 1 & $\begin{array}{l}\text { Low population density } \\
(<1000 / \text { square mile })\end{array}$ \\
\hline CoF & $\mathbf{6}$ & Zone X, low flooding risk \\
\hline
\end{tabular}

Table 9. Case 2 alternate method ranking results 


\section{Conclusion}

An alternate method to calculate the Consequence of Flooding (CoF) is proposed, and evaluated for two areas in South Florida. The proposed method was based on the Failure Mode and Effect Analysis (FMEA) process, an improvement over current $\mathrm{CoF}$ estimation using the Delphi technique. The CoF has three elements: (1) flooding occurrence, (2) severity of flooding, and (3) damage impact control, and each contributes to the total CoF value. This simplified approach is useful for unincorporated areas or areas labelled Zone D by FEMA, which are areas undetermined but with possible flood hazards.

The results from two case studies demonstrate the applicability of this method and address how to expeditiously evaluate undetermined areas with possible flood hazard, or newly incorporated areas in preparation to receive credit toward the CRS classification process, and eventually insurance premium reduction.

This interdisciplinary approach introduces the concept of Failure Mode and Effect Analysis to the flood risk field, and starts a baseline for future improvements to the alternate methodology. Growth of the methodology will evolve into a more probabilistic method, with the inclusion of additional variable, such as, elevation, slope, bathymetry measurements, and area topography.

\section{References}

1. Alexander, M, C. Viavattene, H. Faulkner, and S. Priest (2011). Methods for creating a flood risk assessment tool. Flood Risk Management Research Consortium (FRMRC), report SWP3.2.

2. Asselman, N. E. M., S. N. Jonkman, (2003). Consequences of floods: the development of a method to estimate the loss of life, Delft Cluster report DC1233-7.

3. Baynal, K., T. Sari, and B. Akpinar (2018). Risk management in automotive manufacturing process based on FMEA and grey relational analysis: A case study. Advances in Production Engineering \& Management Vol 13(1):69 - 80.

4. Bell, J. E., C. Langford Brown, K. Conlon, S. Herring, K. E. Kunkel, J. Lawrimore, G. Luber, C. Schreck, A. Smith, and C. Uejio (2018). Changes in extreme events and the potential impacts on human health. Journal of the Air \& Waste Management Association Vol 68(4): 265 - 287.

5. Bloetscher, F. (2020). Watershed Master Planning Pilot Program: Example Watershed Plan, Caloosahatchee Watershed. Florida Atlantic University report to: Florida Division of Emergency Management's (FDEM) Bureau of Mitigation.

6. Bubeck, P., H. de Moel, L. M. Bouwer, and J. C. J. H. Aerts (2011). How reliable are projections of future flood damage? Natural Hazards and Earth System Sciences Vol. 11: 3293 - 3306.

7. Bubeck, P., J. C. J. H. Aerts, H. de Moel, and H. Kreibich (2016). Preface: flood-risk analysis and integrated management. Natural Hazards and Earth System Sciences Vol. 16:1005 - 1010.

8. Chen, A. S., S. Djordjevic, J. Leandro, and D. A. Savic (2010). An analysis of the combined consequences of pluvial and fluvial flooding. Water Science and Technology, 62(7) 1491-1498.

9. Cristaldi, L., M. Faifer, A. Ferrero, and R. Ottoboni (2020). FMEA analysis and metrology: a beneficial synergy. 17th International Measurement Confederation Technical Committee (IMEKO TC-10) and EUROLAB Virtual Conference, Global Trends in Testing, Diagnostics \& Inspection for 2030.

10. Frame, D. J., S. M. Rosier, I. Noy, L. J. Harrington, T. Carey-Smith, S. N. Sparrow, D. A. Stone, and S. Dean (2020). Climate change attribution and economic costs of extreme weather events: a study on damages from extreme rainfall and drought. Climatic Change Vol 162: 781 - 797.

11. Grahn, T. (2017). Risk assessment of natural hazards, data availability and applicability for loss quantification. Doctoral thesis, Faculty of Health, Science and Technology, Karlstad University Studies.

12. Grames, J., A. Prskawetz, D. Grass, A. Viglione, and G. Bloschl (2016). Modeling the interaction between flooding events and economic growth. Ecological Economics Vol 129:193 - 209.

13. Grisa, T. (2012). Relabeling Extreme Rainfall Events so the Public Understands Their Severity. Proceedings of the Water Environment Federation 2013(18).

14. Gueorguiev, T., M. Kokalarov, and B. Sakakushev (2020). Recent Trends in FMEA Methodology. 7th International Conference on Energy Efficiency and Agricultural Engineering (EE\&AE), Ruse, Bulgaria.

15. Jonkman, S. N., J. K. Vrijling, and A. C. W. M. Vrouwenvelder (2008). Methods for the estimation of loss of life due to floods: a literature review and a proposal for a new method. Natural Hazards 46:353 $-389$.

16. Kanelidis, N. (2020). Drainage Report for Boca Raton's Utility Service Complex Master Stormwater Permit Update, City of Boca Raton, Florida. CGA Project No: 10-3619.19.

17. Kellens, W., R. Zaalberg, T. Neutens, W. Vanneuville, and P. De Maeyer (2011). An Analysis of the Public Perception of Flood Risk on the Belgian Coast. Risk Analysis Vol. 31(7):1055 - 1068.

18. Khanal, S., N. Ridder, H. de Vries, W. Terink, and B. van der Hurk (2019). Storm Surge and Extreme River Discharge: A Compound Event Analysis Using Ensemble Impact Modeling. Frontiers in Earth Science 7:224.

19. Li, H., A. P. Teixeira, and C. G. Soarez (2020). A twostage Failure Mode and Effect Analysis of offshore wind turbines, Renewable Energy Vol 162: 1438 1461.

20. Makwana, N, N. and H. R. Thakkar (2014). Review Study of Six Sigma Implementations in Manufacturing Industries. Journal of Emerging Technologies and Innovative Research Vol. 1(7): 744 - 748 . 
21. Mascia, A., A. M. Cirafici, A. Bongiovanni, G. Colotti, G. Lacerra, M. DiCarlo, F. A. Digilio, G. L. Liguori, A. Lanati, and A. Kisslinger (2020). A failure mode and effect analysis (FMEA)-based approach for risk assessment of scientific processes in nonregulated research laboratories. Accreditation and Quality Assurance 25:311-321.

22. McCollum, S. H., O. E. Cruz, L. T. Stem, W. H. Wittstruck, R. D. Ford, and F. C. Watts (1974). Soil Survey of Palm Beach County Area, Florida. United States Department of Agriculture, Soil Conservation Service, in cooperation with University of Florida, Institute of Food and Agricultural Sciences, Agricultural Experiment Station, Soil Science Department.

23. Meeroff, D. E. and F. Bloetscher (2020). Watershed master planning template. Florida Atlantic University report to: Florida Division of Emergency Management's (FDEM) Bureau of Mitigation, Hazard Mitigation Grant Program (HMGP) DR4337-004-P.

24. Mylavarapu, R., W. Harris, and G. Hochmuth (2019). Agricultural Soils in Florida. University of Florida, Institute of Food and Agricultural Sciences (IFAS), Department of Soil and Water Sciences, SL441.

25. O'Geen, A. T. (2013). Soil Water Dynamics. Nature Education Knowledge 4(5):9

26. Perica, S., D. Martin, S. Pavlovic, I. Roy, M. St. Laurent, C. Trypaluk, D. Unruh, M. Yekta, G. Bonnin (2013). NOAA Atlas 14 Volume 9 Version 2, Precipitation-Frequency Atlas of the United States, Southeastern States. NOAA, National Weather Service, Silver Spring, MD.

27. Purvis, M. J., P. D. Bates, and C. M. Hayes (2008). A probabilistic methodology to estimate future coastal flood risk due to sea level rise. Coastal Engineering 55:1062-1073.

28. Rassiah, P., F. F. Su, Y. J. Huang, D. Spitznagel, V. Sarkar, M. W. Szegedi, H. Zhao, A. B. Paxton, G. Nelson, and B. J. Salter (2020). Using failure mode and effect analysis (FMEA) to generate an initial plan checklist for improved safety in radiation treatment. Journal Applied Clinical Medical Physics 21:8:83-91.

29. Scott, M. A. and S. Smith (2019). Stormwater Asset Management in the Heartland: Implementing Asset Renewal into a Successful Flood Reduction Program. Water Environment Federation, Stormwater and Green Infrastructure Symposium 2019, 736 - 745.

30. Sellappan N. and K. Palanikumar (2013). Modified Prioritization Methodology for Risk Priority Number in Failure Mode and Effects Analysis. International Journal of Applied Science and Technology Vol. 3(4).

31. Tanaka, T., K. Kiyohara, and Y. Tachikawa (2020). Comparison of fluvial and pluvial flood risk curves in urban cities derived from a large ensemble climate simulation dataset: A case study in Nagoya, Japan. Journal of Hydrology 584124706.

32. Teegavarapu, R. S. V. (2012). Floods in a Changing Climate, Extreme Precipitation. International Hydrology Series, Cambridge University Press, Cambridge, UK ISBN: 978-1-107-01878-5.
33. Tilley, J. S. and E. T. Slonecker (2007). Quantifying the components of impervious surfaces. Prepared for the U.S. Department of Transportation, Federal Highway Administration. Open file report 2007-1008.

34. Vrouwenvelder, T. (2007). Special workshop on risk acceptance and risk communication. Failure consequences in flood engineering, TNO-Bouw/ Delft University, The Netherlands.

35. Wright, L. D., C. D’Elia, J. Draayer, R. Nichols, D. Resio, R. Weiss, G. Zarillo, L. Azevedo, L. Carnahan, E. Carabantes, K. Caruson, A. Cosby, S. Dalyander, J. Dixon, R. Ersing, J. Garey, S. Graves, C. Hapke, S. Howard, M. Ji, A. Lesen, D. Loftis, M. Luther, G. Mitchum, S. Myers, T. Ruppert, L. Thomas, T. Wahl, S. Watson, R. Weisberg, and K. Xu (2020). Assessing and Planning for the Impacts of Storms, Flooding and Sea Level Rise on Vulnerable Gulf of Mexico Coastal Communities: A White Paper and Program Prospectus. Washington DC, Southeastern University Research Association (SURA), 28 pp.

36. Zhou, Q., P. S. Mikkelsen, K. Halsnaes, and K. Arnbjerg-Nielsen (2012). Framework for economic pluvial flood risk assessment considering climate change effects and adaptation benefits. Journal of Hydrology 414-415:539-549. 